\title{
Devices for mounting of self - drilling metal screws
}

\author{
L. Danylova • T. Waiyaki \\ Igor Sikorsky Kyiv Polytechnic Institute, Kyiv, Ukraine
}

Received: 05 March 2019 / Accepted: 22 March 2019

\begin{abstract}
Purpose. Design, manufacture and test the assembly tools for the self-drilling screws. Devices meet the requirements of hard location the screw, based on the outer diameter of the thread, the inner diameter of the thread or jig bushing, while at the end of the screwing, holding elements pass the head of the screw.

Design/methodology/approach. In a paper it is shown that thread-forming screws, known as self-tapping screws capable of forming or rolling a matching thread into the material into which they are installed requires a hard location of the screw in device to prevent action the radial component of the cutting force. And at the same time devices, that meet the requirements of hard location the screw in the locator, at the end of the screwing let the screw head through them. The presented devices hold the screws for the outer diameter of the thread, the inner diameter of the thread or jig bushing. A device designed to align hex parts, such as screw heads, is also described. Such devices are designed for automated production.

Findings. The developed devices were manufactured and tested. Self-drilling screws drilled holes under the action of axial load, maintaining the correct position and with a free passage of the screw head at the end of drilling. Two of the devices presented are protected by copyright.

Originality/value. In the presented devices assembly with the use of self-drilling forming screws consists in the sequential execution of two diverse operations - first drilling, and then rolling the thread under the action of axial load. In this case, the device rigidly bases the screw, but let the screw head pas sat at the end of drilling. Developed devices can be used in assembly automation.
\end{abstract}

Keywords: SR screws (self-drilling thread screws), self-drilling forming screw, screw connections, assembly automation

Thread-forming screws, known as self-tapping screws capable of forming or rolling a matching thread into the material into which they are installed.

The thread-forming screw displaced material around the pilot hole so that it flows around the screw's threads. In general, tapping screws permit rapid insertion because nuts are not used and access is required from only one side of the joint. Mating threads created by these tapping screws fit the screw threads closely, and no clearance is needed. Tapping screws are used in steel, aluminum, die-castings, cast iron, forgings, plastics, reinforced plastics, and resin-impregnated plywood. Because no material is removed, the mating part creates a fit with zero clearance. They usually do not need lock washers fit or other types of locking devices to prevent loosening [1].

Thus, the installation of SR screws (self-drilling thread screws) is possible using a minimum number of actuators. Assembly with the use of self-drilling forming screws consists in the sequential execution of two diverse operations - first drilling, and then rolling the thread, and the technological process consists in the sequential execution of two traditional methods performed by two tools combined in one body [2].

The difficulty lies in the next, drill requires a hard location of the screw in device to prevent action the radial component of cutting force, the threaded part goes in the obtained hole and its assembly tool should ensure the passage of the screw head.

In modern power screwdrivers a so-called collet Chuck in which the drill is fixed in several (often three) "jaws" symmetrically positioned about an imaginary longitudinal axis of the spindle. The screwdrivers have a device that allows you to limit the depth of screwing of the screw.

For screwing of SR screws the universal adaptation providing hard location of screw cutting part and at the same time passing of the screw head is required. The traditional method of basing screws in flexible elements, allowing the output of the screw head, does not provide proper stability during drilling [3]. 
The following devices meet the requirements of hard location the screw in the locator for the outer diameter of the thread, the inner diameter of the thread or jig bushing, while at the end of the screwing, holding elements let the screw head through them.

For Fig.1c, d and Fig.2 show the photos and drawing of the devices with the conical or cylindrical augers. Between conical or cylindrical augers screw is hold per outer diameter. The screw driver works in the following way. When the spindle 8 and a screwdriver 9 are pulled up the next screw 14, is centered by the spring-loaded inserts 11 , enters the space between the screws 2 so that its head rests on the screw surfaces of the augers screw, and the cylinder body is based between the augers screws.

Thus, the screw is securely held in the desired position. During the rotation of carrier 6 the motion is transmitted to the gears. As the gear 7 has a brake 15, in the initial moment augers 2 rotate and move the screw to touch the detail. Increasing the resistance torque in this direction leads to the rotation of the gear 7,8 the spindle and a screwdriver 9 . A screw is screwed into the detail. In dependence from the conditions of screw driving, rotational motion with different speeds is carried out simultaneously spindle and augers.
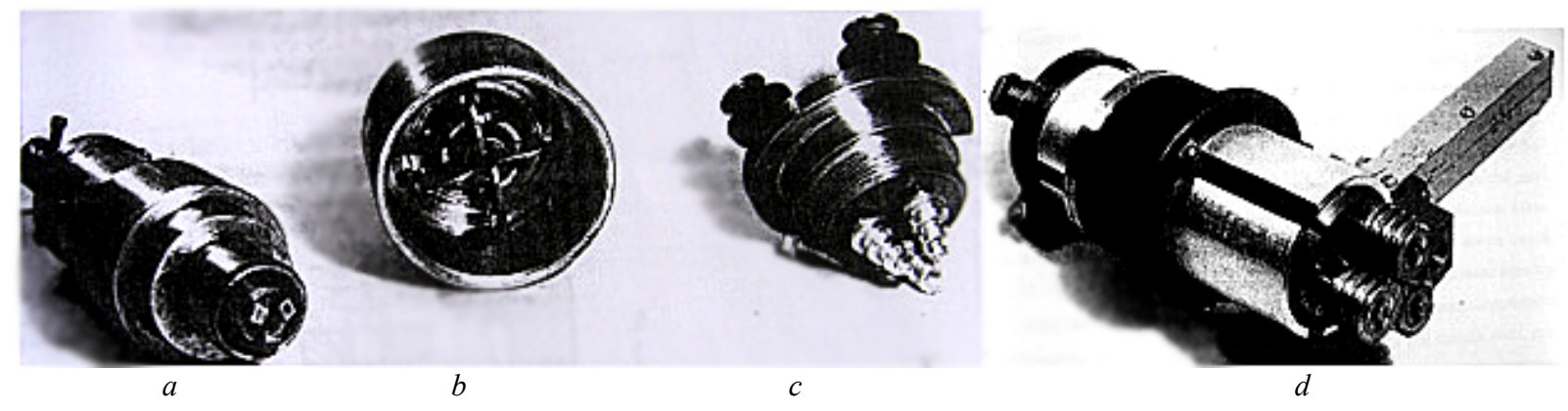

Fig. 1. Photos of screwdrivers: $a$-the head of the screwdrivers; $b$ - a cap piece of the screwdrivers; $c$ - a screwdriver with conical augers; $d$ - a screwdriver with cylindrical augers

Other device (Fig. 1a and Fig. 3) bases the screw in the tappets on the inner diameter of the thread. The device works as follows. At the beginning the spindle 3 is taken up, the screw 15 through the slot in the housing (doesn't shown in the figure) enters the hole 2 and when you move the spindle down screwed into the simulated thread by the pushers 5 . Upon further movement of the head of the screw presses against the stop 7 and moves it in the radial direction, with the larger diameter stops coming out of the hole groove 11 and enters the groove 12, a smaller diameter of the stop enters the groove 11, which ensures their mutual free movement, and the ring 8, free from fixation, is directed upward by the force of the spring 14. In this case, the pushers are drawn into the grooves 4 and 10, providing passage of the screw head. As the screwing all rings rise. For the start of the next cycle, it is necessary to raise the spindle, and just move all the rings down, with the openings of the grooves 11 is aligned with the large diameters of the stops, the latter will enter there by the springs and the rings will once again be fixed, the device is ready for operation [4-8].

The head of the screwdriver, shown in Fig. 4 also rigidly bases the CP screw on the outer diameter of the thread, providing passage of the screw head at the end of screwing. The device works as follows. In the initial position the spring 4 is opened and the column of balls is lifted up to an emphasis in a groove end face. The screw is fed into the area between the balls, and the screw head rests on the columns of the balls. When you move the screw down, its head presses on the balls, moving them along the groove and squeezing the spring 4 . When the last balls pass the rectilinear section of the groove, the screw head is released and freely leaves. As soon as the area between the balls is released, the balls immediately return to their original position by the force of the spring. Moving inserts 3 in the radial direction the device is change setting to the screws of another size [9].

The device, shown in Fig. 1, b and Fig. 5 works as follows. Its working state is shown in the figure. In this case, the spring 5 presses the sleeve 4 till it contacts with the sleeve 6 , in this position, the Cams 8 are drawn together and press the screw head to the end of the rod 2. With the rotation the rod goes down, pulling the bushing 6 , Cams 8 and screw 14. Since the housing 1 rests on the upper detail of the subassembly, then when the spindle go down the distance between the housing and the adapter is reduced, the spring 5 is compressed, and between the sleeve 6 and the ring 12 appears and gradually increases the gap, which leads to the rotation of the Cams 8 and exit them from the working area. After screwing and installation the next screw in the hole 15, the spindle is raised, the clearance is reduced, and the force of the spring 5 saves the fixed position of the sleeve 4, the casing 1 and the ring 12 .

Nozzle to the screwdriver in Fig. 6 works as follows. At the initial moment, the spring 4 is unclamped, the thimble 2 is in its upper position, while the springs 5 are compressed, and the Cams 3 are brought together on the inner diameter of the body. The screw is fed into the device and occupies a position between the Cams, journaling the screw head on the chamfer of the Cams. The screw is rigid basing of on the outer diameter of the thread, since the Cams are based on the 
larger diameter of the hole in the body. When the screw moving down it entrains Cams that experience the pressure of the screw head until the Cams completely out of the zone of the narrow part of the opening of the body. As soon as the Cams are in the area of larger diameter, the screw head move apart them and freely out. Further screwdriving occurs on the already formed threads. As soon as the screw head leaves the Cam zone, the latter are re-unite together by the force

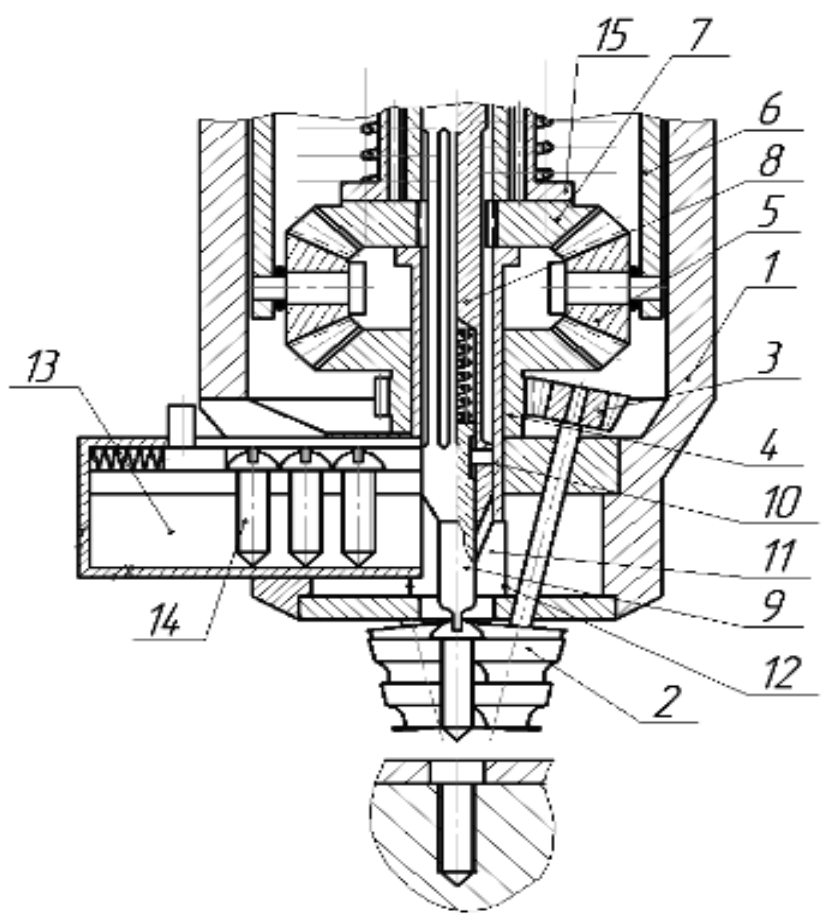

Fig. 2. A screwdriver with cylindrical augers

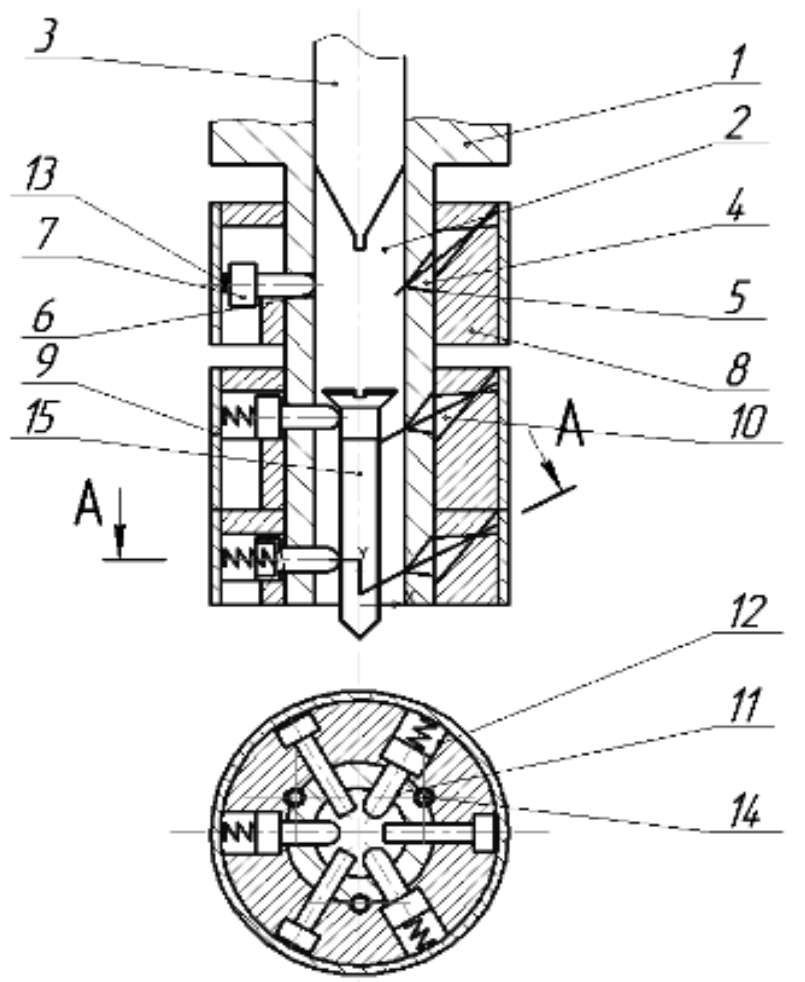

Fig. 3. The head of the screwdrivers 

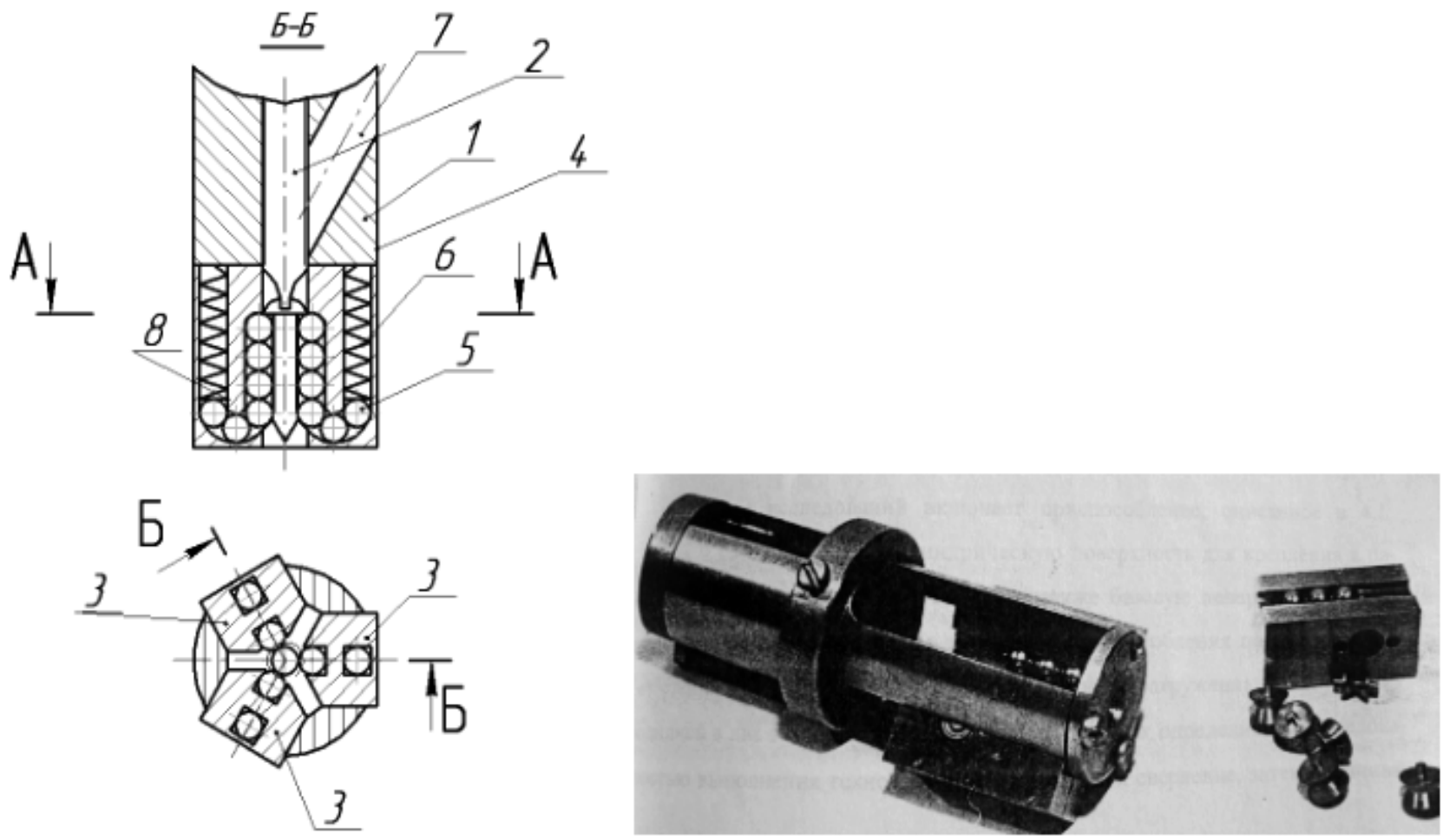

Fig. 4. A cap piece of the screwdrivers

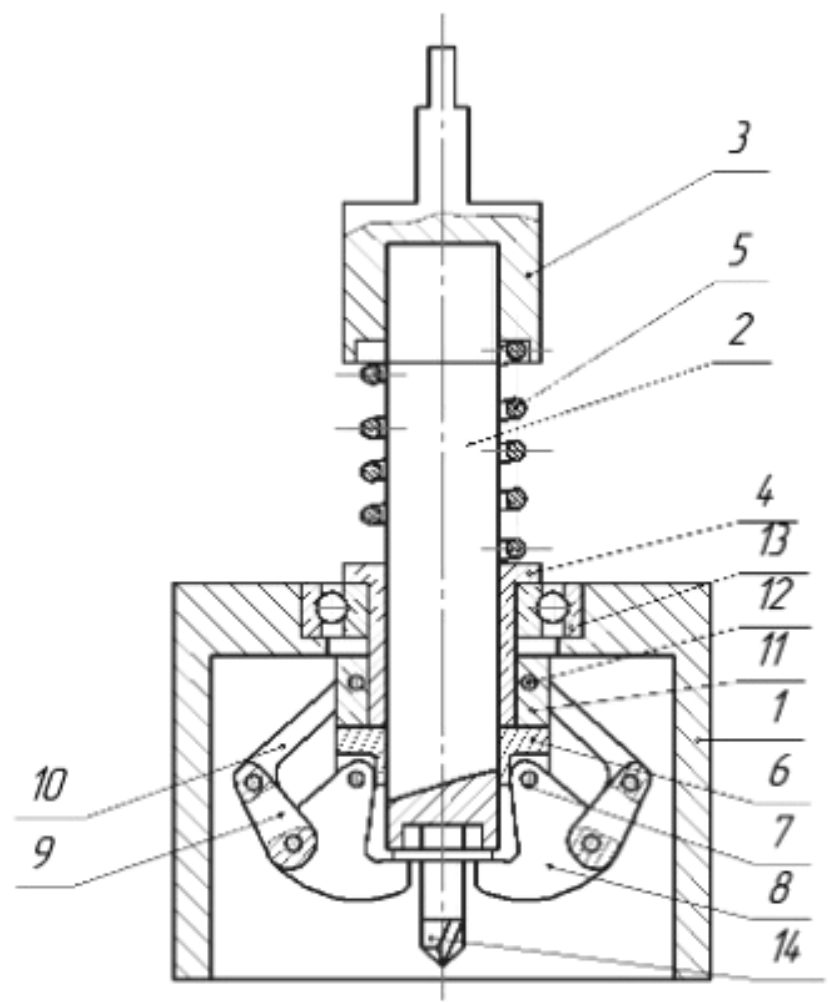

Fig. 5. The head on the screwdriver
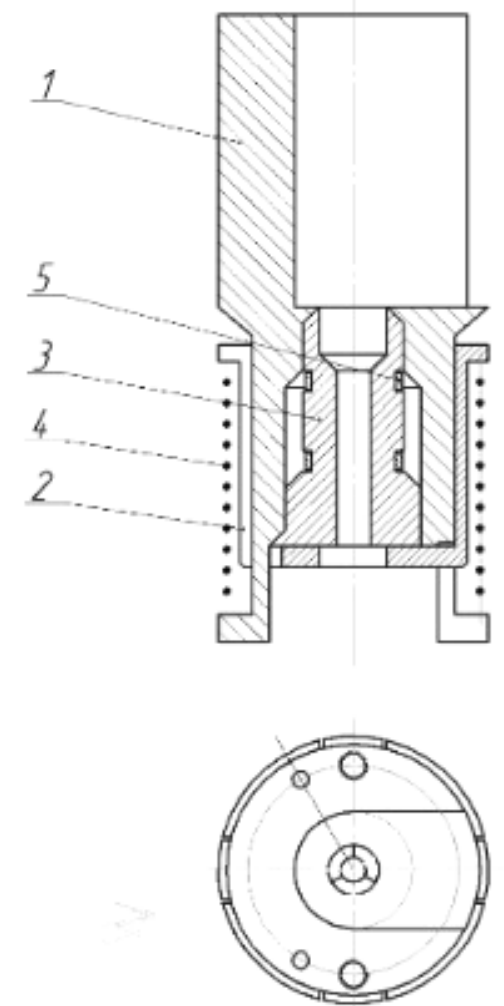

Fig. 6. Nozzle to the screwdriver

of the springs 5, and the thimble 2 by the force of the spring 4 returns the Cams to their original position. To Orient hex parts, such as screw heads, you can use the device shown in the figure. 7 .

The device works as follows. In the initial position, the pusher 9 is in its extreme position the wedge 5 is also withdrawn to the right by the spring 6 . The orientator 7 is located in the groove of the base 1 , but is removed from the tray 2 . Pin 3 is pressed by spring 4 all the way to the horizontal plane of the wedge 5 . The detail enters the tray 1 . The 
elastic pusher 9 moves the wedge 5 to the left, squeezing the spring 6 . The orientator 7 slides into the groove of the base 1 , its elastic end turns the detail of to align the face with the plane of the orientator. Pin 3 is released by spring 4 all the way to the horizontal plane of the wedge 5 .

Upon further movement of the wedge 5 it by his bevel presses the pin 3, compressing the spring 4 , and pin 3 clamp the detail. When the pusher moves to the right, the spring 6 expands and the wedge 5 also moves to the right, its slant slide out the pin 3, it is pressed to the horizontal plane of the wedge 5 by the spring 4 . The orientator 7 slides into the groove 8 of the base 1 and exits tray 2, the groove is empty for the new part [10].

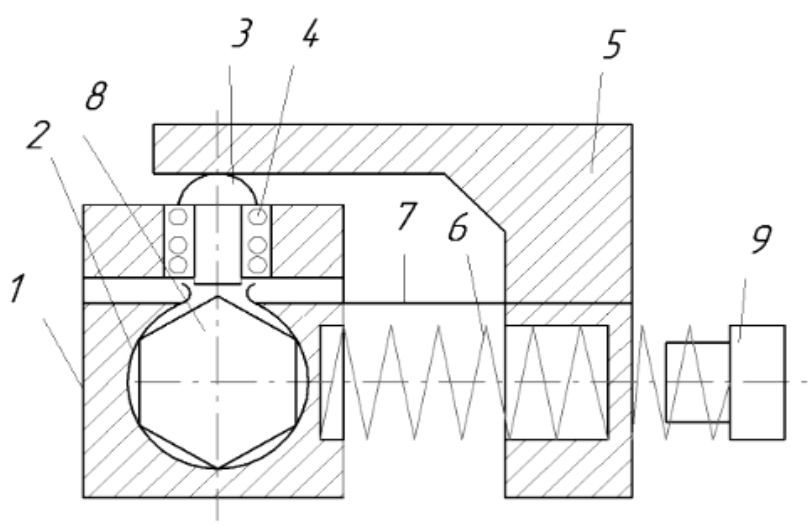

Fig. 7. Orientator

The described devices are universal assembly devices for two different processes - drilling, since they firmly base the screw and prohibit deflection of the SR screws and thread-forming process, since they let the screw head through at the end of the screwing. Constructive integration in one device of elements that satisfy two completely different processes - drilling and thread-forming, complicates the implementation of the thread-screwing process, unless joint technological modes are used. Otherwise, additional devices would be needed, that can provide a change in cutting parameters when transitioning from drilling to threading.

Existing trade off solutions are described in the source [3]. The models of the described devices were made and tested, the test results confirm their functional capability and the possibility of using them in automated productions as well as as screwdriver attachments.

\title{
Пристрої для встановлення самосвердлувальних гвинтів
}

\author{
Л.Н. Данілова, Кіарі Ентоні Вайяки
}

\begin{abstract}
Анотація. У статті представлені деякі варіанти конструкиій пристроїв установлення різьбоформуючих самонарізних гвинтів.

У практиці сучасного машино- $і$ приладобудування широкого поширення набули гвинти, що встановлюються в деталі 3 гладким отвором і зокрема різьбоформуючі самонарізні гвинти, які не потребують стопоріння і додаткових кріпильних деталей. Таким чином, установлення РС (різьбоформуючих самонарізних ) гвинтів можлива із застосуванням мінімальноі кількості виконавчих пристроїв.

Складання із застосуванням РС гвинтів полягає в послідовному виконанні двох різнохарактерних операчій - спочатку свердління, а потім розкочування різьблення. Складність полягає в наступному, свердло вимагає жсорсткого базування для запобігання відведення, або попереднього чентрування, різьбова частина направляється по просвердленій кінцевою частиною отвору, при иьому елементи, що базують, повинні забезпечувати прохід головки гвинта в кінці загвинчування.

Кожний представлений в статті пристрій здійснює жорстке базування гвинтів по зовнішньому або внутрішньому діаметрам різьблення, або базування свердлильної частини по розрізній втулці, при цььому елементи базування не перешкоджають вільному проходженню головки гвинта. Сконструйовані пристрої були виготовлені $і$ випробувані, результат показав, ще вони можуть бути використані в автоматизованому складальному виробнищтві.
\end{abstract}

Ключові слова: ізьбоформуючі самонарізні гвинти, гладко-різьбове з'єднання, автоматизоване складальне виробництво, складальні пристрої. 


\title{
Устройства для установки самосверлящих винтов
}

\author{
Л.Н. Данилова, Киари Ентони Вайяки \\ Аннотация. В статье представлены некоторые варианты конструкций устройств установки самосверлящих \\ резьбовыдавливающих винтов. \\ В практике современного машино- и приборостроения широкое распространение получили винты, устанавливаемые в \\ детали с гладким отверстием и в частности самосверлящие резьбовыдавливающие винты, не требуюшие стопорения и \\ дополнительных крепежных деталей. Таким образом, установка СР (самосверлящих резьбовыдавливающих) винтов \\ возможна с применением минимального количества исполнительных устройств. \\ Сборка с применением самосверлящих резьбоформирующих винтов заключается в последовательном выполнении двух \\ разнохарактерных операчий - сначала сверления, а затем раскатывания резьбы. Сложность заключается в следующем, \\ сверло требует жесткого базирования по двойной направляющей базе для предотвращения увода, или предварительного \\ центрования, резьбовая часть направляется по просверленному концевой частью отверстию, при этом базирующие \\ элементы должны обеспечивать проход головки винта в конце завинчивания. \\ Каждое представленное в статье устройство осуществляет жесткое базирование винтов по наружному или \\ внутреннему диаметрам резьбы, или базирование сверлящей части по разрезной втулке, при этом элементы базирования \\ не препятствуют свободному прохождению иляпки винта. Сконструированные устройства были изготовлены и \\ испытаны, результат показал, что они могут быть использованы в автоматизированном сборочном производстве.
}

Ключевые слова: саморежущие резьбоформирующие винты, гладко-резьбовые соединения, автоматизированное сборочное производство, сборочные устройства.

\section{References}

1. Петриков В. Г. Власов А. П. Прогрессивные крепежные изделия. - М.: Машиностроение, 1991. -256 с.

2. Механизация и автоматизация сборочных работ на машиностроительных предприятиях /Б.М. Арпентьев, А.С. Зенкин, А.Н. Куцин. - К.: Техніка, 1994. - 232 с.

3. Данилова Л.Н. Технологическое обеспечение качества соединений с саморежущими крепежными деталями: Дис. ... канд. техн. наук. - Киев: НТУУ «КПИ», 1998. - 170 с.

4. Березин С.Я., Курбатова Л.С., Леонов В.Н. История изобретений вспомогательной оснастки для резьбонарезных и сборочных операций. //Ученые записки Заб ГГПУ, 2011. №3 (38). -С. 6-14.

5. Березин С. Я., Романова Л. С. Патроны для резьбонарезных и сборочных операций со специальными функциями // Сборка в машиностроении, приборостроении. - 2013. - № 12. - С. 6-13.

6. Курбатова Л. С. Анализ применения вспомогательной оснастки для сборочных и резьбонарезных операций // Учёные записки Забайкальского государственного университета. Серия физика, математика, техника, технология - 2016. -С. 62-63.

7. Жданов А.В., Смирнов В.Ю., Деревенцев М.С., Михайлов Р.Г., Толстобров В.В. Пргнозирование надежности резьбонарезного технологического оборудования. // Научно-исследовательские публикации. - 2015.

8. Березин С. Я., Романова Л. С. Расчет конструктивных и настроечных параметров сборочных и резьбонарезных патронов // Сборка в машиностроении, приборостроении. - 2013. - № 5. - С. 28-34.

9. А.С.1808634 А1. СССР. Головка адаптивного винтоверта. / Л.М. Данилова, В.Н. Давыгора, В.А. Пасечник. - 2c. Ил.: Опубл.15.04.93, Бюл. №14.

10. А.С.№1484582. СРСР. Устройство для ориентации деталей. / Л.Н. Данилова, А.Г. Ярмош. - 2 с. ил.; Опубл. 07.06.89, Бюл. №21. 